\title{
PUBLIC SECTOR AUDIT, TRANSPARENCY AND GOOD GOVERNANCE ON FINANCIAL ACCOUNTABILITY OF PUBLIC SECTOR ENTITIES IN RIVERS STATE, NIGERIA
}

\section{Appah Ebimobowei, Onowu Joseph Uche and Adamu Audu Jibrin}

Department of Accounting, Ignatius Ajuru University of Education, Rumuolumeni P.M.B.

5047, Port Harcourt.

appahebimobowei@yahoo.com; adamunavy1984@gmail.com; uchejoseph@rocketmail.com

Cite this article:

Appah E., Onowu J.U., Adamu A.J. (2021), Public Sector Audit, Transparency and Good Governance on Financial Accountability of Public Sector Entities in Rivers State, Nigeria. African Journal of Accounting and Financial Research 4(3), 1538. DOI: $10.52589 / A J A F R-$ VXJXFZFQ.

\section{Manuscript History \\ Received: 25 June 2021 \\ Accepted: 21 July 2021 \\ Published: 3 Aug 2021}

Copyright $\odot 2020$ The Author(s). This is an Open Access article distributed under the terms of

Creative Commons Attribution-

NonCommercial-NoDerivatives 4.0 International (CC BY-NC-ND

4.0 ), which permits anyone to share, use, reproduce and redistribute in any medium, provided the original author and source are credited.

\begin{abstract}
This study investigated the effects of public sector audit, good governance and financial transparency on financial accountability of twenty - six (26) ministries in the Rivers State Civil Service. The study employed cross sectional survey research design. The population consisted of twenty-eight ministries and the Taro Yamene model was used for sample size determination while simple random sampling was employed. The study used primary and secondary sources of data collection. Questionnaire was the primary source of data collections after the application of content and face validity while Cronbach alpha was employed to test the reliability of the instrument. The dependent variable was financial accountability index while the independent variables consisted of financial audit index, performance audit index, compliance audit index, good governance index and financial transparency index. The responses obtained from the questionnaire were analysed with univariate, bivariate and multivariate analysis. The multiple regression analysis suggested that there is a positive and significant relationship between financial audit index, performance audit index, compliance audit index, good governance index and financial transparency index on accountability in public sectors in Rivers State. The study concluded that public sector audit, good governance and financial transparency promote financial accountability in the Nigerian public sector. Therefore, the following recommendations were provided amongst others that The Accounting Officers in government Ministries, Department and Agencies (MDA) should carry out government business in accordance with accountability, transparency, effectiveness and efficiency, responsiveness, forward vision and rule of law for the welfare of the citizens.
\end{abstract}

KEYWORDS: Public Audit, Transparency, Accountability, Good Governance 


\section{INTRODUCTION}

The level of public sector fraud and misappropriation of funds in many government entities have necessitated various governing and monitoring tools including financial auditing systems (Hazaea, et al 2020). Richard (2019) observed that public sector audits have become a necessity for public sector entities to prevent and detect the level of financial and economic crimes committed by public sector employees and politicians. This level of financial and economic crimes affects the financial performance of government and public sector organizations. Tapang and Ibiam (2019) maintained that the cases of bribery, misappropriation of public funds and theft of government properties have been recorded to be in the order of the day in public sector entities. The authors further stated that public sector audit becomes a method of monitoring and control of the activities of public sector entities. According to Financial Audit Manual (2015), public sector audit which consists of financial audit, regulatory audit and compliance audit are the audit of the financial statements, policies, programmes and operations of public sector organization whereby the auditor expresses an opinion as to whether the financial statements fairly present the financial position and the results of the entity's operation in line with the legal and financial reporting frameworks. Eke (2018) also noted that financial audit involves reviewing evidence to substantiate information contained in the accounting records and financial statements made available to management for decision making. Public sector audit focuses on transactions and events related to revenue or sales, cash, acquisition of assets, expenditure, financial capital receipts and payments, personnel and payroll, as well as external financial reporting. Public sector auditing is the systematic process of objectively obtaining and evaluating relevant and reliable evidence to determine whether information or actual conditions correspond with established criteria. It is basically in providing information and independent and objective examination of the stewardship and performance of government policies, programmes or operations, to legislatures, oversight bodies, those charged with governance and the public.

The need for auditing of financial statements evolved basically as a result of the growing complexity in business. The separation of ownership from management particularly created a need for verification and authentication of results of operations presented in financial statements produced by management who were entrusted with resources by a third party independent of management itself to express an opinion on their truth and fair state (Gupta, 2015). Furthermore, Munene, et al, (2016), added that an effective auditing function can detect and disclose earnings management and other types of misconduct by business managers or controlling shareholders. The main purpose of audit of a financial statement is to provide an independent examination of the financial statements in accordance with generally accepted accounting standards. Notwithstanding the need to maintain a good relationship with the audited company, auditing firms must provide independent auditing services since the financial statements contain substantial economic consequences in decision making by stakeholders. Financial audits do not only generate opinions, but also findings of weaknesses of the internal control system and non-compliance with laws and regulations. This can be a reference for an assessment of the effectiveness and efficiency of an entity in its financial management. This can be a reference for an assessment of the effectiveness and efficiency of an entity in its financial management, as well as an evaluation of the public sector entities in implementing the functions of allocation, stabilization and distribution in the management of public funds. The audit opinion of entities examined by auditors keeps improving, which indicates an increase in the disclosure of financial statements, the improvement of the internal control 
system, as well as the decrease in issues of non-compliance with regulatory requirements, hence the financial performance of public sector entities.

According to Munene, et al, (2016), the auditor of public sector entities is supposed to review and evaluate internal control systems maintained by the organization, which if strong helps to prevent material mis-statements of the financial statements. This audit of public sector entities can be done with a financial audit that reviews and evaluates the internal control system and detection of mis-statements of the financial statements. Zinyama (2013) stated that a public sector audit is to ensure that systems of accounting and financial control are efficient and operating properly and that financial transactions have been correctly authorized and accounted for. Kiabel (2012) noted that the accounting and control practices is believed to be crucial to the success of corporate entities as it acts as a powerful brake on the possible deviations from the predetermined objectives and policies. The author further suggested that this means that an organization that put in place an appropriate and adequate system of accounting controls is likely to perform better (in financial terms) than those that do not. Similarly, Bejide (2006), stated that an effective public sector audit assists to reduce overhead, identify ways to improve efficiency and maximize exposure to possible losses from inadequately safeguarded assets all of which can have a significant effect on the bottom line. There has been evidence of poor accountability in the public sector in Nigeria. This calls for proper and overall audit and effective working of established policies, procedures and operations of government to achieve the effective control and management of public funds. Public sector audit is a medium to ascertain the true financial position of government entities. Despite this important role of public sector auditing, accountability in the public sector has not been proven adequately. Government has invested huge amounts of financial and non-financial resources in the public sector organizations in Nigeria for the purpose of achieving financial accountability and performance. Regrettably, misappropriation, misallocation and embezzlement of funds are still rearing its ugly heads in public sector organizations It is based on these gaps that this study intends to examine the relationship between public sector audit, good governance and transparency on financial accountability of selected public sector entities in Rivers state. The specific objectives are as follows:

1. to investigate the effects of financial audit on financial accountability of public sector entities in Rivers State, Nigeria.

2. to investigate the effects of performance audit on financial accountability of public sector entities in Rivers State, Nigeria.

3. to investigate the effects of compliance audit on financial accountability of public sector entities in Rivers State, Nigeria.

4. to investigate the effects of good governance on financial accountability of public sector entities in Rivers State, Nigeria.

5. to investigate the effects of financial transparency on financial accountability of public sector entities in Rivers State, Nigeria. 
The following research questions guided this study:

1. What is the effect of financial audit on financial accountability of public sector entities in Rivers State, Nigeria?

2. What is the effect of performance audit on financial accountability of public sector entities in Rivers State, Nigeria?

3. What is the effect of compliance audit on financial accountability of public sector entities in Rivers State, Nigeria?

4. What is the effect of good governance on financial accountability of public sector entities in Rivers State, Nigeria?

5. What is the effect of financial transparency on financial accountability of public sector entities in Rivers State, Nigeria?

The following null hypotheses were tested in this study:

H01: There is no significant relationship between financial audit and financial prudence of public sector entities in Rivers State, Nigeria.

H02: There is no significant relationship between performance audit and financial accountability of public sector entities in Rivers State, Nigeria.

H03: There is no significant relationship between compliance audit and financial accountability of public sector entities in Rivers State, Nigeria?

$\mathrm{H0}_{4}$ : There is no significant relationship between good governance and financial accountability of public sector entities in Rivers State, Nigeria?

H05: There is no significant relationship between financial transparency and financial accountability of public sector entities in Rivers State, Nigeria?

\section{LITERATURE REVIEW}

\section{Conceptual Review}

\section{Concept of Public Sector Audit}

Gekula and Isanzu (2020) state that a public sector audit is the audit of the public sector's performance that covers specific financial operations and all government activities, both organizational and administrative systems. Appah (2017) noted that public sector auditing entails the examination of public sector entities financial and non-financial reports that are required to have audited. It is done to ensure that adequate financial records are maintained to form the basis of public stewardship of public funds; proper accountability; prevent embezzlement of public funds; compliance and proper standards of conduct and assist public sector entities achieve value for money (Appah, 2017; Appah \& Zibaghafa; 2018). 
Financial Audit: Financial audit is a type of public sector audit that deals with the accounting and financial control system that ensures efficiency and effective operation of the financial transactions. According to Zinyama (2013), financial audit ensures that the accounting and financial control systems are efficiently and effectively working properly and that financial transactions have been correctly authorized and accounted for. The objective of financial audit is to enhance the objectivity and confidence of the users of financial statements (Appah, 2017). Appah (2017) further noted that financial audit is one that is conducted in order to ensure that the accounting and financial control systems are efficient and cooperating properly; and those financial transactions have been correctly authorized and accounted for. According to Oshisami (2004), financial audit provides examination of financial transactions, accounts and reports and their compliance with applicable regulations to certify that: (a) there are effective controls over revenue, expenditure, assets and liabilities; (b) there proper accounting records of resources, operations and liabilities; (c) the accounting and financial reports are sufficiently accurate, reliable, timely and useful and fairly represent the transactions, events and conditions reported thereon.

Performance Audit: This is the systematic, purposeful, organized and objective of public sector financial activities. According to Ozuomba (2019), performance audit provides managers of public sector entities with management indicators such as leadership, employee empowerment, teamwork, risk assessment, management information, communication, resource allocation, productivity measurement. It is the systematic, objective examination of the processes of public sector activities for the purpose of determining its effectiveness, efficiency, equity, environment and economy. Odia (2014) noted that performance audit provides parliament with an assessment on the performance of these activities with information, observations and recommendations designed to promote accountability in the public sector and ensure an ethical and effective public service, good governance and sustainable development. Ozuomba (2019) further stated that performance audit consists of five elements, namely economy, efficiency, effectiveness, equity and environment.

Compliance Audit: Zinyama (2013) stated that compliance audit verifies that expenditure has been incurred on approved services and in accordance with statutory and other regulations and authorities governing them. Appah (2017) noted that compliance audit is conducted with a view to ensuring that expenditure has been incurred on approved services and in accordance with the enabling statutory provisions and regulations governing the particular expenditure. The following are the documents that can be used in conducting compliance audit: (a) the Nigerian constitution (b) civil service rule (c) treasury circular (d) establishment circular (e) official Gazettes of government (f) financial instructions (g) budgets and (h) financial Acts.

Good Governance: Good governance are governing systems which are capable, responsive, inclusive, and transparent (Gisselquist, 2012). The African Development Bank (2008) defined good governance as a process referring to the manner in which power is exercised in the management of the affairs of a nation, and its relations with other nations. It identifies the key elements of good governance such as accountability, transparency, participation, combating corruption, and the promotion of an enabling legal and judicial framework. Good governance assures that corruption is minimized, the views of minorities are taken into account and that the voices of the most vulnerable in society are heard in decision-making. It is also responsive to the present and future needs of society. The United Nations state that good governance promotes equity, participation, pluralism, transparency, accountability and the rule of law, in a manner that is effective, efficient and enduring. In translating these principles into practice, we 
see the holding of free, fair and frequent elections, representative legislatures that make laws and provide oversight, and an independent judiciary to interpret those laws. The Organization for

Economic Cooperation and Development (OECD) identified the elements of good governance to include: accountability, transparency, effectiveness and efficiency, responsiveness, forward vision and rule of law.

Financial Transparency: Transparency is the ability of the society to discern clearly that a particular leader or officer is carrying out his duties to the letter without fear, favour or personal benefit. Honesty is the hallmark of transparency (Okwoli, 2004). It can also be defined as an ethical concept implying openness, honesty and forthrightness in official dealings and relationships. It is the negation of corruption and unwholesome practices in the public service (Adebayo, 2004). Transparency is a moral virtue, which stresses sincerity, truthfulness and openness. Since operators in the public sector are trustees in a sense, they necessarily must be honest; otherwise, they will abuse the confidence and trust reposed in them by the public and this will ultimately lead to lack of confidence in the essence of government as institutions (Abata \& Adejuwon, 2012). Transparency refers to unfettered access by the public to timely and reliable information on decisions and performance in the public sector. It is about the sharing of information about government decisions and activities, good records management and access to information that are of interest to all segments of the society, investors, the research and development, community, the media and the ordinary citizen. Ake (1993) observes that one would have left the track of exhibiting transparency when there is no violation of moral principles surrounding an officer jurisdiction. The author explained further that transparency is closely associated with morality, that is, those practices and activities seen as right or wrong by members of the society.

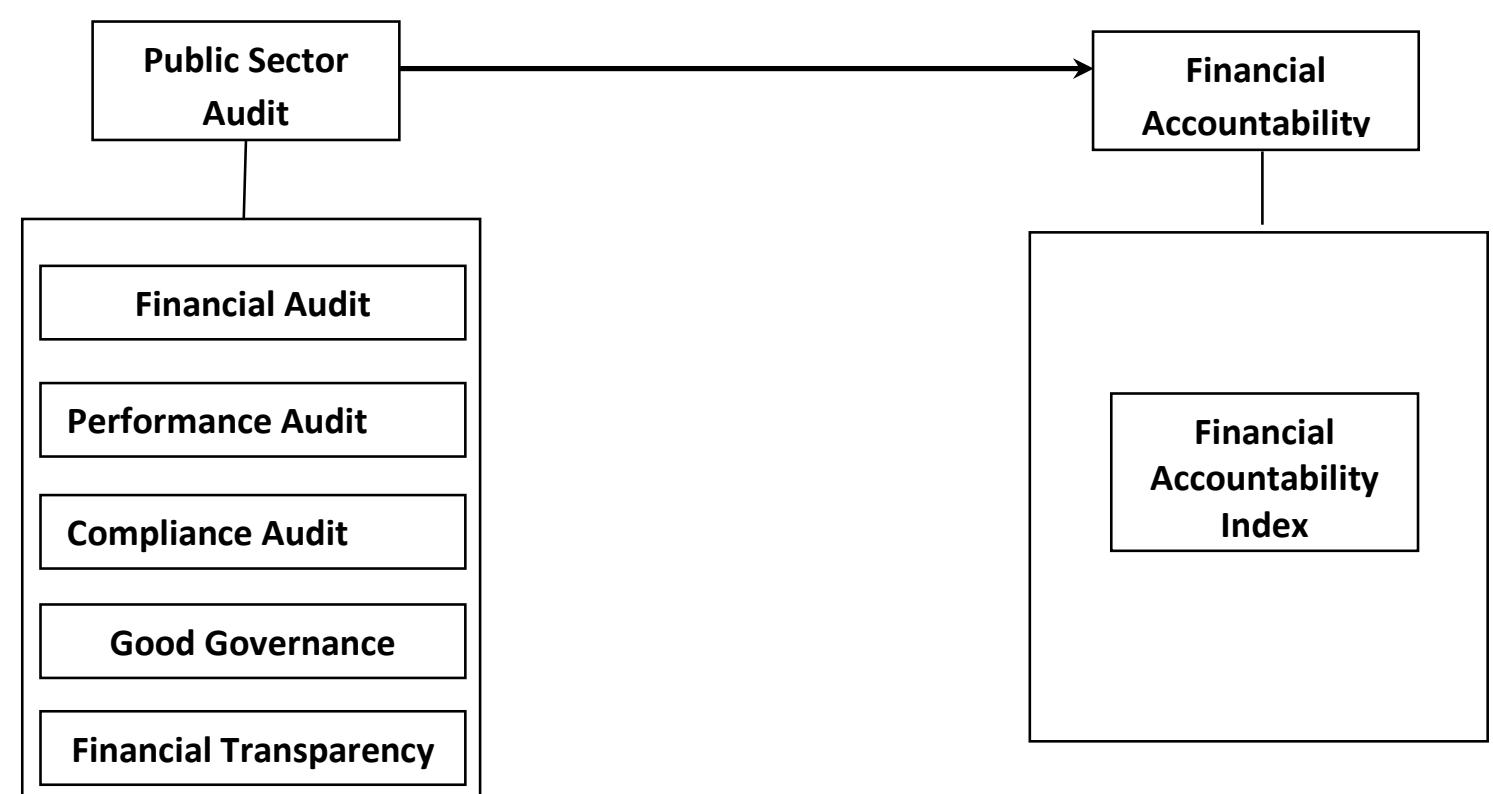

Figure 1: Public Sector Audit and Financial Accountability 


\section{Concept of Financial Accountability}

Accountability is a very important concept in public sector financial management of resources. According to Onurah and Appah (2012), accountability is the obligation to show that activities and responsibilities of public sector activities are conducted in accordance with set policies, procedures, rules and standards and the officer reports fairly and accurately on performance results vis-à-vis mandated roles and or/plans. Oloruntoba and Gbemigun (2019) noted that the concept of accountability refers to the legal and reporting framework, organizational structure, strategy, procedures and actions to assist ensure that public sector entities use public funds and make decisions that influence people's lives and can be held responsible for their actions. Almquist et al (2013); Jorge de Jesus and Eirado (2012) stated that accountability in the public sector requires governments to answer to the society to justify the financial sources and the utilization of public funds. Financial accountability is the combination of the legal and economic rationality and emphasizing probity, compliance, efficiency of public sector entities. It includes efficiency and effective use of financial and non-financial resources (Appah \& Zibaghafa, 2018; Zeyn, 2018). It involves the minimization of the misappropriation of public funds (Mohamad, et al, 2015). Adegite (2010) further stated that accountability is the obligation to demonstrate that work has been conducted in accordance with agreed rules and standards and the officer reports fairly and accurately on performance results vis-à-vis mandated roles and or/plans. It means doing things transparently in line with due process and the provision of feedback. Johnson (2004) noted that public accountability is an essential component for the functioning of our political system, as accountability means that those who are charged with drafting and/or carrying out policy should be obliged to give an explanation of their actions to their electorate

\section{Theoretical Review}

An independent external auditor ensures that the financial statements are credible to be relied upon by stakeholders like trade creditors, bankers, stockholders, government and other interested third parties in the decision making process. Audited financial statements are now in the current business environment the established means by which organizations can state their operating results and financial position. Hayes, et al (2015) identified four theories of auditing which explains the existence of auditing namely; Policeman theory, lending credibility theory, inspired confidence theory and agency theory.

Agency theory: Meckling and Jensen (2000), agency relationship contract exists between one or more persons-the principal and another person (agent) to perform some service on their behalf, which involves delegating some decision making authority to the agent. Agency theory evolution also owes much to the corporate governance literature, which analyzes the problem of separation of ownership and control (Grabling et al., 2004). In the construction industry, an internal audit practice plays an important role in reducing both information asymmetry by empirically confirming the validity of financial statements and agency problems. The principalagent conflict is illustrated in agency theory, where the principal (owner) lacks reasons to believe their agents (managers) due to information asymmetries and contradictory motives (Hillebrandt, 2000). Jensen and Meckling (1976), states that in agency theory, agents have more information than principals and this information asymmetry adversely affects the principals' ability to monitor whether or not their interests are being properly served by the agents. The agency theory proposes that a firm's main objective is to maximize the shareholders wealth. The theory states that the organization consists of principals who are the 
owners of the economic resources and the agents who are the managers of the principal's resources. One objection to agency theory is that it relies on an assumption of self-interested agents who seek to maximize personal economic wealth. The agency theory helps the study to explain the existence of internal audit in organizations but can also help explain some of the characteristics of the internal audit department, for example, its size, and the scope of its activities, such as operational internal auditing versus financial performance within the organization. Agency theory contends that internal auditing, in common with other intervention mechanisms like financial reporting and external audit, helps to maintain cost-efficient contracting between owners and managers, through cost efficiency leading to financial performance within the organization.

Inspired Confidence Theory: This theory suggests that the primary function of the audit is to add credibility to the financial statements. The user's confidence is increased upon relying on audited financial statements rather than the financial statements presented by the management. The management therefore uses the audited financial statements to enhance stakeholder's faith in their managerial performance. Lending credibility theory is used by the management on the firm's audited financial statements to assure the stakeholder's of quality in management's leadership. In this view, the service that the auditors are selling to the clients is credibility (Watts, 2010). The theory helps the study to explore or to explain the auditor's report in order to comment on how accurately the bank presents its financial situation and how it is performing. This should support the shareholders that their investment is secured and also help to reduce the practice of misleading accounting procedures designed to show the company in a more favorable light. Essentially, the internal audit is represented as a process designed to evaluate the credibility of information of a bank's financial statements (Hayes et al, 2015).

Lending Credibility Theory: (Hayes et al, 2015) stated that the primary function of the audit is to add credibility to the financial statements. The user's confidence is increased upon relying on audited financial statements rather than the financial statements presented by the management. The management therefore uses the audited financial statements to enhance stakeholder's faith in their managerial performance. The users are perceived to gain benefits from the increased credibility, these benefits are typically considered to be that the quality of investment decisions improve when they are based on reliable information (Hayes et al. 2015). The audited financial statements enhance principal agent's relationship and reduce information asymmetry. Akinbuli (2010) states that audited financial statements can enhance stakeholders' faith in management's stewardship.

Policeman Theory: Under this theory, an auditor acts as a policeman focusing on arithmetical accuracy and on prevention and detection of fraud. This theory allows the auditor to detect and prevent errors and fraud in organizations. The management should establish and maintain strong internal control systems to enhance prevention and detection of fraud and any other irregularities within the organization. It is not the responsibility of the auditor to look for fraud unless he enters into a specific agreement with the management to do so. However, if the audit is properly carried out the work of the auditor should expose fraud and irregularities where they exist. The main focus of auditors is verification of the truth and fairness of the financial statements and provision of reasonable assurance. The detection of fraud is however still a hot topic in the debate on the auditor's responsibilities and typically after events where financial statement frauds have been revealed, the pressure increases on increasing the responsibilities of auditors in detecting fraud (Hayes et al, 2015). The theory helps the study to provide reasonable assurance and verify the fairness and truth of financial statements and increase 
responsibility to internal auditors to discover the financial frauds, increases physical control, information processing controls and monitoring its led internal auditors to gain skills and competence which bring positive impacts on financial performance.

\section{Empirical Review}

Ozuomba (2019) investigated performance audit and accountability of public sector entities in Nigeria. The study employed cross sectional survey research design. The study population consisted of all public sector entities while the accessible population comprised the power sector in Nigeria. The study adopted secondary sources of data collection while augmented dickey fuller, unit root test, descriptive statistics and multiple regression was used for the purpose of data analysis. The dependent variable was funding while the independent variable was effectiveness, equity and environment. The results from the multiple regression analysis disclosed that there is a positive and significant relationship between effectiveness and funding; equity and funding and environment and funding. The study therefore concluded that the conduct of the regular public sector does improve the ability of public sector managers to disclose timely and adequate accountability of public funds.

Agbatogun (2019) examined financial accountability and management of the public sector in Nigeria. The study utilized cross sectional survey research design and the study employed primary and secondary sources of data collection. The primary data was a well-designed and structured questionnaire after validity and reliability of the instrument. The questionnaire was analysed using descriptive, t-test, correlation matrix and multiple regression. The dependent variable was management for service delivery (MSD) while the independent variables consisted of good governance (GG), financial accountability (FA) and financial transparency (FT). The multiple regression result disclosed a positive relationship between good governance practice and service delivery capacity; financial accountability and service delivery capacity; and financial transparency and service delivery capacity. The author concluded that for accountability to be successful in the public sectors in Nigeria. it is important that public office holders should be made to be held accountable for management of public fund

Richard (2109) carried out an investigation of internal audit and profitability of the banking sector in Kenya based on a case study of Commercial Banks in Kericho Town. The study focused on the effectiveness of internal audit in Commercial Banks, to determine factors affecting profitability of Commercial Banks, and to establish the relationship between quality of internal audit and profitability. The data were collected using a questionnaire and interview schedule. The study had a sample size of 30 employees sampled from various commercials in Kericho town using stratified random sampling method. The research findings indicated that: internal auditors contribute to profitability of firms mainly through detection of fraud and advising management on internal control systems; also, it indicated that the major constraints to internal audit effectiveness were lack of independence and lack of enough qualified audit staff. Profitability of Commercial Banks was mainly affected by high tax liability on profits, low productivity per employee and increasing cost of production. Furthermore, it established that effective internal audits influence the profitability of firms.

Zeyn (2018) investigated internal audit quality and financial accountability of local governments of West Java and Benten in Indonesia. The study employed a cross sectional survey research design. The target population consisted of the Local Government Inspectorate at West Java and Benten while the sampling technique was the saturated sample of 27 from 
West Java and 9 from Benten. The independent variable was internal audit quality while the dependent variable was financial accountability quality. The study used primary and secondary sources of data collection. The questionnaire was the major source of primary data used for the analysis. The primary data obtained from the questionnaire were analysed using univariate and multivariate analysis. The result revealed that internal audit quality factors the financial accountability of local governments in West Java and Benten, Indonesia.

Asaolu, et al (2016) examined the effect of internal audit function (IAF) on good governance in the public sector in Nigeria. The main objective of the study was to determine the role of the internal audit function in ensuring good governance in the public sector in Nigeria. Primary data for the study were obtained using structured questionnaires and data analysis was done using correlation analysis and multiple regression techniques. The study found that internal audit moderately contributes to the effectiveness of corporate governance in the public sector in Nigeria and concluded that the internal audit function is a veritable tool for promoting good governance in the Nigerian public sector. The study recommended that there should be a legal mandate in public sector organisations that allows government information to be publicly published and that special funds should be made available to internal auditors as it would enhance the effectiveness of the internal audit function and boost good governance in public organisations.

In another study, Changwony and Rotich (2015) examined the role of internal audit function in promoting effective corporate governance of commercial banks in Kenya. The purpose of the study was to determine the role of the internal audit function in promoting effective corporate governance of commercial banks in Kenya. Survey design was adopted for the study and stratified sampling technique used in selecting the sample elements. The findings of the study revealed that internal audit has a positive and significant influence on effective corporate governance. The study concluded that the internal audit function plays a positive and significant role in promoting effective corporate governance of commercial banks in Kenya. The study recommended that the audit committee should take responsibility for approving the appointment, remuneration and disengagement of the Chief Audit Executive to enhance the effectiveness of the internal audit function.

Harrison (2015) assessed the influence of internal audit independence on the financial performance of small and medium enterprises: a case of the construction industry in Mombasa County, Kenya. From the researcher, it was evident that some construction companies within Mombasa County did not accord the internal auditors the independence they deserved to effectively give their opinion on the financial statements of the organizations. Some records in some organizations were not accessed by the auditors to enable them perform their work comprehensively. In some companies the auditors were treated as part of the management thus making it difficult for them to form an independent opinion on the financial statements. Although the auditors had the required qualifications in some cases, the management of the organizations did not appreciate that. The auditors had their roles of ensuring that the management of the firms discharged their responsibilities through giving them the required advice.

Odoyo and Omwono (2014) investigated the role of internal audit in enhancing corporate governance for companies listed at the Nairobi stock exchange. The objectives of the study were: to assess the auditor's role in corporate governance, to assess the internal audit's capacity to achieve its objectives, and to suggest how internal auditors' independence can be achieved. 
The descriptive research design was used and the data collection instrument was the questionnaire. The study employed both stratified and systematic sampling procedures. The sample size was thirty (30) companies quoted in the Nairobi stock exchange. The study found that eighty four (84) percent of the respondents were of the opinion that internal audit influences corporate governance of companies listed in the Nairobi stock exchange, hence it was concluded that the internal audit function contributes to corporate governance. One of the recommendations made in the study was that the internal auditor should report functionally to the audit committee and administratively to the chief executive officer of the organization.

In another study, Mohammed, Unuigbokhai, and Ihimekpen (2014) investigated the role of internal audit in strengthening corporate governance in Nigeria. The main purpose of the study was to examine at a theoretical level the contribution of internal auditing to corporate governance. The study also examined the interaction between various corporate governance factors such as the board of directors, the audit committee and the external auditor, and the internal audit process. To achieve the objectives of the study, the researchers conducted an extended literature review. The study found that a positive relationship exists between internal audit and corporate governance and concluded that internal audit plays a vital role in strengthening corporate governance in Nigeria. The study recommended that case study research be carried out by scholars to determine the impact of internal auditing on corporate governance in particular organisations.

Abdullah (2014) carried out an investigation on 'redefining internal audit performance: impact on corporate governance'. The specific purpose of the study was to explore the ways internal auditing is practiced in Malaysian public listed companies and as such establish internal audit's contribution to corporate governance of such companies. The study adopted the survey research design and data were collected using mail questionnaires and interviews. Analysis of data was done using the Rasch model. The findings of the study reveal that internal audit has a significant impact on corporate governance and those collaborations particularly in risk management, information technology audits and quality audits, are increasingly being used as a strategy in internal audit to provide value-added services. It concluded that internal audit significantly influences corporate governance of Malaysian public listed companies and recommended that the practice of internal audit in future should be more collaborative to harness the expertise and experience of other departmental personnel in producing effective internal audit, ultimately creating a greater impact on corporate governance.

Oloruntoba and Gbemigun (2019) investigated accountability and public sector performance in Nigeria. The study employed cross sectional research design and the population consisted of 150 respondents from the Osi Local Government Area of Osun State of Nigeria. A total of 120 questionnaires were administered and 90 were returned. The study used simple random sampling method technique and the data obtained from the questionnaire was analysed using percentages and chi square technique. The results disclosed that there is a relationship between appraisal of integrity of public office holders and performance output within a short and long period in Ose Local Government Area of Osun State, Nigeria.

Njunwa (2013) conducted a study on internal audit and corporate governance in local governments in Tanzania, using Mwanza city council as a case study. The primary objective of the study was to determine the factors that contribute to ineffectiveness of the internal audit function in promoting good corporate governance in the public sector in Tanzania. Data were obtained primarily using structured questionnaires. The study which adopted the multiple 
regression approach to data analysis found that factors such as lack of independence, lack of proficiency of internal auditors as well as lack of integrity on the part of internal auditors contributed to the ineffectiveness of the internal audit function in Mwanza city council and hence the public sector in Tanzania. The study concluded that the internal audit function in Mwanza city council does not promote good corporate governance. Consequently, it was recommended that internal auditors should ensure they improve their skills to enable them perform better and assist the council in promoting good corporate governance.

\section{METHODOLOGY}

In discussing the methodology, the researcher concentrates on the research design, population of the study, sample and sampling techniques, instrumentation, validity of instrument, reliability of instrument, administration of instrument and method of data analysis.

\section{Research Design}

According to Appah (2020), a research design is the blueprint for the collection, measurement and analysis of data. A research design is the plan of a research work by a researcher or a comprehensive outline the shows how a research study will take place. It can be seen as the glue that holds together all of the components in a research project. The research design shows that the researcher is able to tackle the research problem in a coherent and explicit way. This study basically adopted correlation survey research design. According to Appah (2020), correlation study is a quantitative method of research in which the researcher has two variables from the same group of participants and tries to determine if there is a relationship between the two variables. The correlation survey design was adopted because the study intends to determine the relationship between public sector audit and financial accountability of public sector entities in Rivers State Nigeria.

\section{Population of the study}

According to Appah (2020), research population can be defined as the aggregate of elements, events, conceivable traits, people, subjects or observations having the same characteristics, relating to the situation of interest in the study to be conducted. Population simply means the total or aggregate number of people or items covered by the study. It is also used in research and statistics to represent the entity to be investigated (Appah, 2020). The target population of the study is made up of all accountants and auditors in twenty-six Ministries in Rivers State, Nigeria.

\section{Sample and Sampling Technique}

A Sample is the smallest group of elements drawn through a definite procedure from a specified population; the elements making up this sample are those that are actually studied (Appah, 2020). This study employed simple random sampling. The author's choice of simple random sampling technique is because it is by far the earliest and simplest probability sampling in terms of conception and application. The study used the Taro Yamene model to derive the sample size of 24 Ministries in Rivers State, Nigeria. 


\section{Instrumentation}

The instrument used for collecting data for this study was designed by the researcher taking into consideration the objectives of the study. The instrument was named Public Sector Audit and Financial Accountability Questionnaire (PSAFAQ). It comprised five sections. Section one provides information on the biodata of the respondents; section two consists of questions on financial audit; section three consists of questions on performance audit ; section four consists of questions on compliance audit and section five consists of questions on financial accountability index. A total of two hundred and forty (240) questionnaires were administered to the 24 Ministries in Rivers State, Nigeria and a total of one hundred and fifty six (156) questionnaires were retrieved and used for the purpose of data analysis.

\section{Validity and Reliability of Instrument}

The study used content validity where the instrument was given to experts in Rivers State University and Ignatius Ajaru University of Education, Port Harcourt who read through and made necessary corrections. The instrument was administered to twenty-five (25) respondents of the target population who were not part of the respondents and after a period of two weeks, the same instruments again were given to the same twenty-five (25) respondents to ascertain the reliability. The Cronbach alpha $U$ was used to determine the statistical reliability of 0.78 , which implies the instrument is reliable. A Cronbach alpha value that is above 0.5 (that is $50 \%$ ) is reliable and values between 0.7 and 0.9 is very reliable.

\section{Method of Data Analysis}

The methods of data analysis involve mathematical and statistical formulas used in analyzing the outcome of the research hypothesis and questions. Hence, Consistent with the positivist research philosophy and quantitative design, the study employed technique of inferential analysis in this study is parametric statistics. This technique is associated with the use of quantitative models that seek to establish correlational relationships between two variables by using sample-based parameters as measures to infer about the population of the study. The data analysis was executed in three distinct stages. Firstly, a univariate (or descriptive) analysis was executed, followed by bivariate analysis and lastly, multivariate analysis. The multivariate analysis used multiple regression that was guided by the model below:

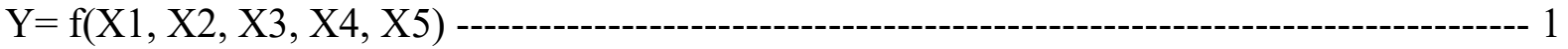

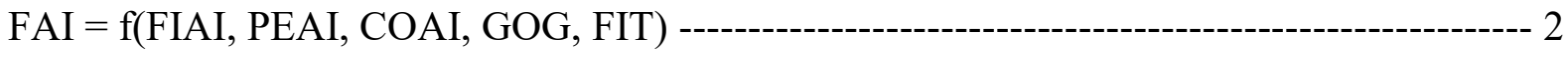

$$
\begin{aligned}
& \mathrm{FAI}=\beta_{0}+\beta_{1} \mathrm{FIAI}+\beta_{2} \mathrm{PEAI}+\beta_{3} \mathrm{COAI}+\beta_{4} \mathrm{GOGI}+\beta_{5} \mathrm{FITI}+\varepsilon-\overline{-}-\mathrm{-}
\end{aligned}
$$

Where:

FAI = Financial Accountability Index $;$ FIAI = Financial Audit Inventory $;$ PEAI $=$ Performance Audit Inventory; COAI = Compliance audit Inventory, GOG $=$ Good Governance; FIT = Financial Transparency and $\varepsilon=$ error term. The priori expectation: $\beta 1-\beta 5>0$. E-view was applied in the analysis of data. The SPSS reports $p$ values which can be used as an alternative approach in assessing the significance of regression coefficients. The $p$ value shows what is the smallest level at which we would be able to accept the null hypotheses of a test. We used a $5 \%$ level of significance; hence we conclude that the coefficient is significantly different from 
zero at the $5 \%$ level if the p-values is less than or equal to 0.05 . If it is greater than 0.05 then we cannot reject the null hypothesis that the coefficient is actually zero at our $5 \%$ significance level.

\section{RESULTS AND DISCUSSION}

\section{Analysis of Respondents Characteristics}

Table 1: Gender Respondents

\begin{tabular}{|l|c|c|}
\hline Sex & Frequency & Percentage \\
\hline Male & 104 & 66.67 \\
\hline Female & 52 & 33.33 \\
\hline Total & 156 & 100 \\
\hline
\end{tabular}

Source: Field Survey, 2021

Table 1 shows gender respondents. $66.67 \%$, which translated to 104 respondents', are male, while $33.33 \%$, which translated to 52 respondents are female. This indicates that the male were more represented than females.

Table 2: Age of Respondents

\begin{tabular}{|l|c|c|}
\hline Sex & Frequency & Percentage \\
\hline Under 30 years & 25 & 16.02 \\
\hline $\mathbf{3 1}-\mathbf{4 0}$ years & 48 & 30.77 \\
\hline $\mathbf{4 1}-\mathbf{5 0}$ years & 56 & 35.90 \\
\hline $\mathbf{5 1}-\mathbf{6 0}$ & 27 & 17.31 \\
\hline Total & 156 & 100 \\
\hline
\end{tabular}

Source: Field Survey, 2021

Table 2 reveals the age of respondents. 25 respondents representing $16.02 \%$ were under 30 years of age, 48 respondents representing $30.77 \%$ were $31-40$ years, 56 respondents representing $35.90 \%$ were 41 - 50 years and 27 respondents representing $17.31 \%$ were $51-60$ years.

Table 3: Respondents Educational Qualification

\begin{tabular}{|l|c|c|}
\hline Sex & Frequency & Percentage \\
\hline Bachelor's Degree & 84 & 53.85 \\
\hline Master's Degree & 58 & 37.18 \\
\hline PhD Degree & 4 & 2.56 \\
\hline Professional Qualification & 10 & 6.41 \\
\hline Total & 156 & 100 \\
\hline
\end{tabular}

Source: Field Survey, 2021 
Table 3 shows respondents' educational qualifications. 84 respondents representing $53.85 \%$ had bachelor's degree, 58 respondents representing 37.18 had master's degree, 4 respondents representing $2.56 \%$ had $\mathrm{PhD}$ degree while 10 respondents representing $6.41 \%$ had professional qualifications.

\section{Table 4: Respondents Years of Service}

\begin{tabular}{|l|c|c|}
\hline Sex & Frequency & Percentage \\
\hline $\mathbf{1 - 1 0}$ & 26 & 16.67 \\
\hline $\mathbf{1 1}-\mathbf{2 0}$ & 78 & 50.00 \\
\hline Above 20 years & 52 & 33.33 \\
\hline Total & 156 & 100 \\
\hline
\end{tabular}

Source: Field Survey, 2021

Table 4 reveals respondents' years of service. 26 respondents representing $16.67 \%$ had spent 1 - 10 years, 78 respondents representing $50 \%$ had spent $11-20$ years while 52 respondents representing $33.33 \%$ had spent above 20 years in the Rivers State Civil Service.

Table 5: Output of Stationarity Test for Unit Root

\begin{tabular}{|l|l|l|l|l|}
\hline Variable & $\begin{array}{l}\text { ADF } \\
\text { Level }\end{array}$ & $\begin{array}{l}\text { ADF } \\
\text { First Difference }\end{array}$ & $\begin{array}{l}\text { Philips -Perron } \\
\text { Level }\end{array}$ & $\begin{array}{l}\text { Philip Perron } \\
\text { First Difference }\end{array}$ \\
\hline FAI & -3.734385 & -5.913238 & -4.080133 & -5.604378 \\
\hline FIAI & -5.205633 & -5.117080 & -5.205577 & -5.117080 \\
\hline PEAI & -5.401524 & -6.382351 & -5.401524 & -6.382351 \\
\hline COAI & -4.048278 & -6.982531 & -4.016975 & -6.982531 \\
\hline GOGI & -4.708267 & -8.677968 & -4.791522 & -8.944514 \\
\hline FITI & -5.150467 & -6.696784 & -4.096982 & -6.626784 \\
\hline Critical Value: & & & & \\
$1 \%$ & -3.621023 & -3.626784 & -3.621023 & -3.626784 \\
$5 \%$ & -2.943257 & -2.945842 & -2.943427 & -2.945842 \\
$10 \%$ & -2.610263 & -2.611531 & -2.610263 & -2.611531 \\
\hline
\end{tabular}

Source: Eview Output for Stationarity of Data

Table 5 shows the unit root test for stationarity of data. The result suggests that financial accountability index (FAI), financial audit index (FIAI), performance audit index (PEAI), compliance audit index (COAI), good governance index (GOGI) and financial transparency index (FITI) with ADF of $-3.734385,-5.205633,-5.401524,-4.048278,-4.708267$ and 5.150467 is less than -3.621023 for $1 \%,-2.9432257$ for $5 \%$ and -2.610263 for $10 \%$ at level data 1(0) and for Philip Perron test financial accountability index (FAI), financial audit index (FIAI), performance audit index (PEAI), compliance audit index (COAI), good governance index (GOGI) and financial transparency index (FITI) with -4.080133, -5.205577, -5.4010524, $-4.016975,-4.791522$ and -4.096982 . The result reveals that the variables are stationary at $\mathrm{I}(0)$. 


\section{Analysis of Research Questions}

\section{Research Question One}

What is the effect of financial audit on financial accountability of public sector entities in Rivers State, Nigeria?

Table 6: Financial Audit and Financial Accountability in Rivers State

\begin{tabular}{|l|c|c|}
\hline Options & Frequency & Percentage \\
\hline Strongly agree & 65 & 41.67 \\
\hline Agree & 49 & 31.41 \\
\hline Not Sure & 10 & 6.41 \\
\hline Disagree & 24 & 15.38 \\
\hline Strongly disagree & 8 & 5.13 \\
\hline Total & 156 & 100 \\
\hline
\end{tabular}

Source: Field Survey, 2021

Table 6 shows financial audit and financial accountability in Rivers State. 65 respondents representing $41.67 \%$ strongly agree that financial audit affects financial accountability of public sector entities in Rivers State; 49 respondents representing $31.41 \% \%$ agree that financial audit affects financial accountability of public sector entities in Rivers State; 10 respondents representing $6.41 \%$ are not sure whether financial audit affects financial accountability of public sector entities in Rivers State; 24 respondents representing $15.38 \%$ disagree that financial audit affects financial accountability of public sector entities in Rivers State; and 8 respondents representing 5.13\% strongly disagree that financial audit affects financial accountability of public sector entities in Rivers State. Hence 114 respondents stated that financial audit affects the level of financial accountability in public sector entities in Rivers State, Nigeria.

\section{Research Question Two}

What is the effect of performance audit on financial accountability of public sector entities in Rivers State, Nigeria?

Table 7: Performance Audit and Financial Accountability in Rivers State

\begin{tabular}{|l|c|c|}
\hline Options & Frequency & Percentage \\
\hline Strongly agree & 60 & 38.46 \\
\hline Agree & 52 & 33.33 \\
\hline Not Sure & 14 & 8.97 \\
\hline Disagree & 20 & 12.82 \\
\hline Strongly disagree & 10 & 6.42 \\
\hline Total & 156 & 100 \\
\hline
\end{tabular}

Source: Field Survey, 2021 
Table 7 shows performance audit and financial accountability in Rivers State. 60 respondents representing $38.46 \%$ strongly agree that performance audit affects financial accountability of public sector entities in Rivers State; 52 respondents representing 33.33\%\% agree that performance audit affects financial accountability of public sector entities in Rivers State; 14 respondents representing $8.97 \%$ are not sure whether performance audit affects financial accountability of public sector entities in Rivers State; 20 respondents representing $12.82 \%$ disagree that performance audit affects financial accountability of public sector entities in Rivers State; and 10 respondents representing 6.42\% strongly disagree that performance audit affects financial accountability of public sector entities in Rivers State. Hence 112 respondents stated that performance audit affects the level of financial accountability in public sector entities in Rivers State, Nigeria.

\section{Research Question Three}

What is the effect of compliance audit on financial accountability of public sector entities in Rivers State, Nigeria?

Table 8: Compliance Audit and Financial Accountability in Rivers State

\begin{tabular}{|l|c|c|}
\hline Options & Frequency & Percentage \\
\hline Strongly agree & 68 & 43.59 \\
\hline Agree & 54 & 34.62 \\
\hline Not Sure & 6 & 3.85 \\
\hline Disagree & 18 & 11.54 \\
\hline Strongly disagree & 10 & 6.40 \\
\hline Total & 156 & 100 \\
\hline
\end{tabular}

Source: Field Survey, 2021

Table 8 shows compliance audit and financial accountability in Rivers State. 68 respondents representing $43.59 \%$ strongly agree that compliance audit affects financial accountability of public sector entities in Rivers State; 54 respondents representing 34.62\%\% agree that compliance audit affects financial accountability of public sector entities in Rivers State; 6 respondents representing 3.85\% are not sure whether compliance audit affects financial accountability of public sector entities in Rivers State; 18 respondents representing $11.54 \%$ disagree that compliance audit affects financial accountability of public sector entities in Rivers State; and 10 respondents representing $6.40 \%$ strongly disagree that compliance audit affects financial accountability of public sector entities in Rivers State. Hence 112 respondents stated that compliance audit affects the level of financial accountability in public sector entities in Rivers State, Nigeria.

\section{Research Question Four}

What is the effect of good governance on financial accountability of public sector entities in Rivers State, Nigeria? 
Table 9: Good Governance and Financial Accountability in Rivers State

\begin{tabular}{|l|c|c|}
\hline Options & Frequency & Percentage \\
\hline Strongly agree & 60 & 38.46 \\
\hline Agree & 74 & 47.44 \\
\hline Not Sure & 07 & 4.49 \\
\hline Disagree & 10 & 6.41 \\
\hline Strongly disagree & 05 & 3.20 \\
\hline Total & 156 & 100 \\
\hline
\end{tabular}

Source: Field Survey, 2021

Table 9 shows good governance and financial accountability in Rivers State. 60 respondents representing $38.46 \%$ strongly agree that good governance affects financial accountability of public sector entities in Rivers State; 74 respondents representing $47.44 \%$ agree that good governance affects financial accountability of public sector entities in Rivers State; 07 respondents representing $4.49 \%$ are not sure whether good governance affects financial accountability of public sector entities in Rivers State; 10 respondents representing $6.41 \%$ disagree that good governance affects financial accountability of public sector entities in Rivers State; and 05 respondents representing 3.20\% strongly disagree that good governance affects financial accountability of public sector entities in Rivers State. Hence 134 respondents stated that good governance affects the level of financial accountability in public sector entities in Rivers State, Nigeria.

\section{Research Question Five}

What is the effect of financial transparency on financial accountability of public sector entities in Rivers State, Nigeria?

Table 10: Financial Transparency and Financial Accountability in Rivers State

\begin{tabular}{|l|c|c|}
\hline Options & Frequency & Percentage \\
\hline Strongly agree & 57 & 36.54 \\
\hline Agree & 68 & 43.60 \\
\hline Not Sure & 07 & 4.49 \\
\hline Disagree & 16 & 10.26 \\
\hline Strongly disagree & 8 & 5.11 \\
\hline Total & 156 & 100 \\
\hline
\end{tabular}

Source: Field Survey, 2021

Table 10 shows financial transparency and financial accountability in Rivers State. 57 respondents representing $36.54 \%$ strongly agree that financial transparency affects financial accountability of public sector entities in Rivers State; 68 respondents representing $43.60 \% \%$ agree that financial transparency affects financial accountability of public sector entities in Rivers State; 7 respondents representing $4.49 \%$ are not sure whether financial transparency 
affects financial accountability of public sector entities in Rivers State; 16 respondents representing $10.26 \%$ disagree that financial transparency affects financial accountability of public sector entities in Rivers State; and 8 respondents representing 5.11\% strongly disagree that financial transparency affects financial accountability of public sector entities in Rivers State. Hence 125 respondents stated that financial transparency affects the level of financial accountability in public sector entities in Rivers State, Nigeria.

Table 11: Correlation Analysis

\begin{tabular}{|c|c|c|c|c|c|c|}
\hline & FAI & FIAI & PEAI & COAI & GOGI & FITI \\
\hline \begin{tabular}{|} 
Pearson Correlation & FAI \\
& FIAI \\
PEAI \\
COAI \\
GOGI \\
FITI
\end{tabular} & $\begin{array}{l}1.000 \\
.064 \\
-.039 \\
.047 \\
.015 \\
-.063\end{array}$ & $\begin{array}{l}.064 \\
1.000 \\
.121 \\
-.421 \\
.148 \\
.207\end{array}$ & $\begin{array}{l}.039 \\
.121 \\
1.000 \\
-.174 \\
.452 \\
.275\end{array}$ & $\begin{array}{l}.047 \\
-.421 \\
-.174 \\
1.000 \\
-.148 \\
130\end{array}$ & $\begin{array}{l}.015 \\
.148 \\
452 \\
-.148 \\
1.000 \\
.081\end{array}$ & $\begin{array}{l}.063 \\
.207 \\
.275 \\
.130 \\
.081 \\
1.000\end{array}$ \\
\hline $\begin{array}{l}\text { FAI } \\
\text { FIAI } \\
\text { PEAI } \\
\text { COAI } \\
\text { GOGI } \\
\text { FITI }\end{array}$ & $\begin{array}{l}.201 \\
.304 \\
.268 \\
.419 \\
.204\end{array}$ & $\begin{array}{l}.201 \\
.055 \\
.060 \\
.025 \\
.464\end{array}$ & $\begin{array}{l}.304 \\
.055 \\
.011 \\
.056 \\
.071\end{array}$ & $\begin{array}{l}.268 \\
.060 \\
.011 \\
.025 \\
.043\end{array}$ & $\begin{array}{l}.419 \\
.025 \\
.056 \\
.025 \\
.143\end{array}$ & $\begin{array}{l}.204 \\
.464 \\
.071 \\
.043 \\
.143\end{array}$ \\
\hline
\end{tabular}

Source: SPSS Output (2021)

The correlation matrix from table 11 showed the extent of the relationship between the dependent variable (FAI) and the independent variables (FIAI, PEAI, COAI, GOGI and FIFI). The correlation coefficient $(0.064,0.039,0.047,0.015$, and 0.063$)$ shows a low positive correlation between FAI and all the independent variables. This implies that the independent variables influence the dependent variable.

\section{Analysis of Research Hypotheses}

Table 12: Multiple Regression Analysis

Dependent Variable:

Method: Least Squares

Date: 04/20/21 Time: 15:58

Sample(adjusted): 156

Included observations: 156 after adjusting endpoints 


\begin{tabular}{crllr}
\hline \multicolumn{1}{c}{ Variable } & Coefficien & Std. Error & t-Statistic & Prob. \\
& $\mathrm{t}$ & & & \\
\hline C & 3.275444 & 2.256856 & 1.451330 & 0.1488 \\
FIAI & 0.285935 & 0.095662 & 2.989017 & 0.0033 \\
PEAI & 0.249495 & 0.106627 & 2.339885 & 0.0206 \\
COAI & 0.216547 & 0.102573 & 2.111150 & 0.0363 \\
GOGI & 0.273341 & 0.123184 & 2.218965 & 0.0400 \\
FITI & 0.220526 & 0.104976 & 2.100727 & 0.0327 \\
\hline R-squared & 0.418414 & Mean dependent var & 12.99346 \\
Adjusted R-squared & 0.361218 & S.D. dependent var & 3.098167 \\
S.E. of regression & 2.888766 & Akaike info criterion & 4.997962 \\
Sum squared resid & 1226.711 & Schwarz criterion & 5.116803 \\
Log likelihood & -376.3441 & F-statistic & 5.567008 \\
Durbin-Watson stat & 2.16401 & Prob(F-statistic) & 0.000100 \\
\hline
\end{tabular}

Source: e-view output

Table 12 shows the multiple regression analysis for public sector audit and financial accountability in public sector entities in Rivers State, Nigeria. The result suggests that financial audit, performance audit, compliance audit, good governance and financial transparency with p-values of $0.0033,0.0206,0.0363,0.0400$ and 0.0327 is less than the critical value of 0.05 . Hence, we deduce that there is a positive and significant relationship between public sector audit and financial accountability in public sector entities in Rivers State, Nigeria. The $\mathrm{R}^{2}$ (coefficient of determination) of 0.418414 and adjusted $\mathrm{R}^{2}$ of 0.361218 shows that the variables combined determines about $42 \%$ and $36 \%$ of public sector accountability in Rivers State, Nigeria. The F-statistics and its probability shows that the regression equation is well formulated explaining that the relationship between the variables combined are statistically significant $(\mathrm{F}$-stat $=5.567008 ;$ F-pro. $=0.000100)$.

\section{Hypothesis One}

There is no significant relationship between financial audit and financial prudence of public sector entities in Rivers State, Nigeria.

Table 12 suggests that $0.0033<0.05$, hence rejecting the null hypothesis and accepting the alternative hypothesis that there is a significant relationship between financial audit and financial prudence of public sector entities in Rivers State, Nigeria.

\section{Hypothesis Two}

There is no significant relationship between performance audit and financial accountability of public sector entities in Rivers State, Nigeria.

Table 12 suggests that $0.0206<0.05$, hence rejecting the null hypothesis and accepting the alternative hypothesis that there is a significant relationship between performance audit and financial prudence of public sector entities in Rivers State, Nigeria. 


\section{Hypothesis Three}

There is no significant relationship between compliance audit and financial accountability of public sector entities in Rivers State, Nigeria?

Table 12 suggests that $0.0363<0.05$, hence rejecting the null hypothesis and accepting the alternative hypothesis that there is a significant relationship between compliance audit and financial prudence of public sector entities in Rivers State, Nigeria.

\section{Hypothesis Four}

There is no significant relationship between good governance and financial accountability of public sector entities in Rivers State, Nigeria?

Table 12 suggests that $0.0400<0.05$, hence rejecting the null hypothesis and accepting the alternative hypothesis that there is a significant relationship between good governance and financial accountability of public sector entities in Rivers State, Nigeria.

\section{Hypothesis Five}

There is no significant relationship between financial transparency and financial accountability of public sector entities in Rivers State, Nigeria?

Table 12 suggests that $0.0327<0.05$, hence rejecting the null hypothesis and accepting the alternative hypothesis that there is a significant relationship between performance audit and financial transparency of public sector entities in Rivers State, Nigeria.

\section{CONCLUSION AND RECOMMENDATIONS}

This study empirically investigated the effects of public sector audit, good governance and transparency on financial accountability of public sector entities in Rivers State, Nigeria. The study employed primary data from a structured questionnaire for data collection. The questionnaire was tested using face validity and Cronbach alpha method of reliability test. The population of the study consisted of twenty-eight ministries and the Taro Yamene formula was used for the determination of a sample size of twenty six ministries. The questionnaire responses were analysed with univariate, bivariate and multivariate analysis. The multiple regression analysis revealed that there is a positive and significant relationship between financial audit, performance audit, compliance audit, good governance practices and financial transparency of financial accountability of public sector entities in Rivers State, Nigeria. Hence, the study concluded that the application of financial audit, performance audit, compliance audit, good governance practices and financial transparency by public sector managers in Rivers State, Nigeria would promote sound public financial management practices, and hence financial accountability in the Nigerian public sector. Therefore, the study made the following recommendations: 
1. Managers (Accounting Officers) of public sectors should ensure that financial audits are done annually as a means of providing financial accountability of public sector governance;

2. The Accounting Officers in government Ministries, Department and Agencies (MDA) should ensure that governance financial activities are properly done within government policies, rules and financial regulations.

3. The Accounting Officers in government Ministries, Department and Agencies (MDA) should carry out government business in accordance with accountability, transparency, effectiveness and efficiency, responsiveness, forward vision and rule of law.

\section{REFERENCES}

Abdullah, R. B. (2014). Redefining internal audit performance: Impact on corporate governance. http://ro.ecu.edu.au/theses/1567.

Adegite, E. O. (2010). Accounting, accountability and national Development, Nigerian Accountant, 43(1): 56-64.

Ado, A. B., Rashid, N., Mustapha, U. A., \& Ademola, L. S. (2020). The impact of audit quality on the financial performance of listed companies Nigeria. Journal of Critical Reviews, 7(9), 37- 42. https://doi.org/10.31838/jcr.07.09.07

Agbatogun, T.O. (2019). Financial Accountability, transparency and management of the Nigerian public sector. Accounting and Taxation Review, 3(1), $104-117$.

Almquist, R., Grossi, G., van Helden, G. J. \& Reichard, C. (2013). Public sector governance and accountability. Critical Perspectives on Accounting, 24(7-8), 479-487.

Appah, E. \& Zibaghafa, S. (2018). Anatomy of public sector finance and accounting, Vinson Publishers.

Appah, E. (2020). Research methodology: Integration of principles, methods and techniques, Vinson Publishers.

Appah. E. (2017). Auditing and assurance services (2nd ed.), Periscopic Media and Publishing House.

Asaolu, T.O., Adedokun, S.A. \& Monday, J.U. (2016). Promoting good governance through internal audit function: The Nigerian experience. International Business Research, 9(5), 196-204.

Changwony, M.K. \& Rotich, G. (2015). Role of internal audit function in promoting effective corporate governance of commercial banks in Kenya. International Journal of Business \& Law Research, 3(1), 15-33.

Eke, G.O. (2018). Internal audit and corporate governance effectiveness in universities in Rivers State. European Journal of Accounting, Auditing and Finance Research, 6(4), 35 $-58$.

Etengu, R.O., \& Amony, M. (2016). Internal control system and financial performance in nongovernmental organisations in Uganda: A case study of the international union for conservation of nature. International Journal of Contemporary Applied Sciences, 3(2), $328-347$.

Financial Audit Manual (2015). Office of the Auditor General of Nepal, Babermahal, Kathmandu. 
Gekula, J. \& Isanzu, J. (2020) The effects of internal auditing on financial performance of public sector organization in Tanzania: A case of IIala Municipal Council. International Journal of Research and Analytical Review, 7(3), 478-491.

Gisselquist, R.M. (2012).Good governance as a concept and why this matters for development policy. World Institute for Development Research, United Nations University.

Hayes, R., Dassen, R., Schilder, A. \& Wallage, P. (2015). Principles of Auditing: An introduction to international standards in auditing (3rd ed.), Prentice Hall.

Hazaea, S.A., Tabash, M.I., Khtib, S.F.A., Zhu, J. \& Al-Kuhali, A.A. (2020). The impact of internal audit quality on financial performance of Yemeni commercial banks: An empirical investigation. Journal of Asian Finance, Economics and Business, 7(11), 867875.

Johnson, I. E. (2004). Public Sector Accounting and Financial Control. Financial Institutions Training Centre.

Jorge de Jesus, M. \& Eirado, J. S. B. (2012). Relevance of accounting information to public sector accountability: A study of Brazilian federal public universities. Tékhne, 10(2), 87-98.

Kiabel, B.D. (2012). Internal audit and performance of government enterprises: A Nigerian study. Global Journal of Management and Business Research, 12(6), 4-20.

Kinyua, J.K. (2016). Effect of internal control systems on financial performance of companies quoted in the Nairobi securities exchange. (Unpublished $\mathrm{PhD}$ thesis). Jomo Kenyatta University of Agriculture and Technology, Kenya.

Mohamad, A. A-A., Hilmi, A-R. M-M. \& Alamc, J. S. (2015). Enhancement of the accountability of public sectors through integrity system, internal control system and leadership practices: A Review Study. Procedia Economics and Finance, 28 (12) 163 169.

Muraleetharan P. (2010), Internal control and its impact on financial performance of organization university of Jaffnan.

Njunwa, F (2013). Internal audit and corporate governance in local governments in Tanzania: A case of Mwanza city council. (Unpublished MBA Dissertation). Mzumbe University, Tanzania.

Odia, J.O. (2014). Performance auditing and public sector accountability in Nigeria: The roles of supreme audit institutions. Asian Journal of Management Sciences and Education, 3(2), 102 - 109.

Odoyo, F.S. \& Omwono, G.A. (2014). The role of internal audit in enhancing corporate governance for companies listed at the Nairobi stock exchange. Research Journal of Finance and Accounting, 5(3), 56-61.

Oloruntoba, S.F. \& Gbemigun, C.O. (2019). Accountability and public sector performance in the third world country: A case study of Nigeria. International Journal of Trend in Scientific Research and Development, 3(3), 218-225.

Onurah, A.C. \& Appah, E. (2012). Accountability and public sector financial management in Nigeria. Arabian Journal of Business and Management Review (OMAN Chapter), 1(6), $1-17$.

Oshisami, K. (2004). Government Accounting and Financial Control, Spectrum Books Limited.

Ozuoba, N.T. (2019). Performance audit and accountability of the public sector in Nigeria. International Journal of Innovative Finance and Economic Research, 7(2), 1-9. 
Rahim, A. (2019). Governance and good governance - A conceptual perspective. Journal of public administration and governance, 9(3), $113-123$.

Richard, K. (2019). Internal audit and profitability of banking institutions in Kenya: A case study of commercial banks in Kericho County, Kenya. Scientific Research Journal, V1l (V), 46-61. http://dx.do.org/10.31364/SCIRJ/V7.15.2019.PO19652

Tapang, A.T. \& Ibiam, O. (2019). Internal audit and financial performance of microfinance banks in Nigeria. International Journal of Social Sciences and Management, 5(4), 95107.

Tehrani, R. \& Ghorbani, A.H. (2013). Operational auditing vs traditional method A comparative investigation. Management Science Letter, 3, 1805 - 1814.

Zinyama, T. (2013). Efficiency and effectiveness in public sector auditing: An evaluation of the comptroller and auditor general's performance in Zimbabwe from $1999-2012$. International Journal of Humanities and Social Sciences, 3(7), 267 - 282. 